\title{
Pemodelan Transportasi pada Jalan Trans Bangka Menggunakan Aplikasi PTV Visum
}

\author{
GHINA ARIQOH UFAIROH YUNUS, HERMAN, ANDREAN MAULANA \\ Jurusan Teknik Sipil, Institut Teknologi Nasional, Bandung \\ Email: ghinariqoh95@gmail.com
}

\begin{abstract}
ABSTRAK
Dalam kehidupan sehari-hari manusia tidak bisa lepas dengan namanya transportasi, namun transportasi saat ini kurang diimbangi dengan fasilitas yang ada. Pada penelitian ini lokasi yang ditinjau adalah Jalan Trans Bangka dengan zona kabupaten di Pulau Bangka. Pemodelan dilakukan dalam empat tahap pemodelan transportasi dan pembebanan dilakukan dengan metode pembebanan Keseimbangan Wardrop menggunakan aplikasi PTV Visum. Berdasarkan hasil validasi arus lapangan dengan arus model dapat dikatakan valid karena $R^{2}$ yang didapat dari grafik memiliki nilai mendekati 1 yaitu 0,86. Pergerakan yang terjadi setelah dibangunnya jalan Trans Bangka pada tahun 2020 menunjukkan hasil arus rata-rata untuk kendaraan penumpang sebesar $170 \mathrm{smp} / j a m$ dengan kecepatan $52 \mathrm{~km} / \mathrm{jam}$ dan kendaraan barang sebesar $165 \mathrm{smp} / \mathrm{jam}$ dengan kecepatan $51 \mathrm{~km} / \mathrm{jam}$. Hal ini dapat diartikan kendaraan penumpang yang melewati jalan Trans Bangka lebih besar dibandingkan dengan kendaraan barang. Derajat kejenuhan yang didapat pada jalan Trans Bangka tahun 2020 menunjukkan nilai yang relatif kecil atau <0,85.
\end{abstract}

Kata kunci: jaringan jalan, PTV Visum, keseimbangan wardrop

\section{ABSTRACT}

Everyday life people can't escape with the name of transportation, but the current transportation is less balanced with existing facilities. In this study the location reviewed is Trans Bangka Road with the district zone in Bangka Island. Modeling is done in four stages of transport modeling and loading is done by loading method of Wardrop Balance using PTV Visum application. Based on the results of validation results that the flow field with the flow of the model can be said to be valid because $R^{2}$ obtained from the graph has a value close to 1 that is 0.86. The movement occurring after the construction of Trans Bangka road in 2020 shows the average current flow for passenger vehicles of $170 \mathrm{smp} /$ hour with speed $52 \mathrm{~km} /$ hour and for goods vehicles of $165 \mathrm{smp} / \mathrm{hour}$ with speed $51 \mathrm{~km} / \mathrm{hour}$. It can be interpreted that passenger vehicle passing through Trans Bangka road is bigger compared to goods vehicle. The degree of saturation obtained on the Trans Bangka road in 2020 shows a relatively small value of $<0.85$.

Keywords: road network, PTV Visum, wardrop equilibrium 


\section{PENDAHULUAN}

Dalam kehidupan sehari-hari manusia tidak bisa lepas dari namanya transportasi. Transportasi merupakan peranan penting bagi kehidupan manusia dalam mempercepat perjalanannya untuk mencapai tujuan.

Jalan Trans Bangka yang akan dibangun melewati beberapa kabupaten di Pulau Bangka. Dibangunnya jalan Trans Bangka ini diharapkan dapat mempercepat pergerakan orang maupun barang di wilayah tersebut, juga menjadi jalan alternatif yang strategis dalam upaya peningkatan perekonomian masyarakat Bangka Belitung.

Pemodelan transportasi bertujuan untuk mengetahui mengenai pola pergerakan lalu lintas kendaraan dan kinerja lalulintas yang terjadi dalam ruas jalan tersebut. Pembebanan dengan metode keseimbangan wardrop (equilibrium) dipilih dengan asumsi dasar setiap pengendara akan berusaha meminimumkan biaya perjalanannya dengan beralih menggunakan rute alternatif.

Tujuan dari penelitian ini yaitu menganalisis pergerakan lalu lintas kendaraan penumpang dan barang yang terjadi sesudah dibangunnya jalan Trans Bangka dan menganalisis kinerja ruas jalan pada lalu lintas jalan Trans Bangka.

PTV Visum dipilih sebagai perangkat lunak pemodelan pergerakan transportasi untuk analisis kinerja lalu lintas pada ruas jalan Trans Bangka.

\section{TINJAUAN PUSTAKA}

\subsection{Tinjauan Umum}

Perencanaan transportasi adalah suatu perencanaan kebutuhan prasarana transportasi seperti jalan, terminal, pelabuhan, serta sarana untuk mendukung sistem transportasi yang aman dan efisien serta berwawasan lingkungan. Konsep perencanaan transportasi yang telah berkembang sampai saat ini yaitu Model Perencanaan Transportasi 4 Tahap diantaranya yaitu Bangkitan dan Tarikan Pergerakan (Trip Generation), Sebaran Pergerakan (Trip Distribution), Pemilihan Moda (Moda Split), dan Pemilihan Rute (Trip Assignment) (Tamin. O. Z., 2000).

\subsection{Konsep Perencanaan}

Konsep Perencanaan dalam melakukan pemodelan jaringan jalan ini menggunakan model empat tahap, model empat tahap tersebut yaitu:

1. Bangkitan atau Tarikan Pergerakan

Bangkitan pergerakan adalah tahapan pemodelan yang memperkirakan jumlah pergerakan yang berasal dari suatu zona atau tata guna lahan dan jumlah pergerakan yang tertatik ke suatu tata guna lahan atau zona. Bangkitan lalulintas ini mencakup lalulintas yang meninggalkan suatu lokasi dan lalulintas yang menuju atau tiba ke suatu lokasi (Tamin. O. Z., 2000).

2. Sebaran Pergerakan

Sebaran Pergerakan adalah bagian dari proses perencanaan transportasi yang berhubungan dengan pergerakan antar zona dan menghubungkan interaksi antara tata guna lahan, jaringan tranportasi, dan arus lalulintas. Hasil dari tahap ini adalah Matrik Asal Tujuan (MAT). Matrik Asal Tujuan (MAT) adalah matrik bermata dua yang berisi infomasi mengenai besarnya pergerakan antar lokasi (zona) didalam daerah tertentu. Baris menyatakan zona asal dan kolom menyatakan zona tujuan, sehingga sel matriknya menyatakan besarnya arus dari zona asal ke zona tujuan (Tamin. O. Z., 2000). 


\section{Pemilihan Moda}

Pemilihan moda terjadi jika interaksi terjadi antara dua tata guna lahan di suatu kota, seseorang akan memutuskan bagaimana interaksi tersebut harus dilakukan salah satunya dengan pemilihan moda menggunakan kendaraan (pribadi atau umum) ataupun berjalan kaki (Tamin. O. Z., 2000).

4. Pemilihan Rute

Pemilihan rute dapat diklasifikasikan berdasarkan beberapa faktor pertimbangan yang didasarkan atas pengamatan bahwa tidak semua pengendara dari suatu lokasi menuju lokasi lainnya akan memilih suatu rute yang persis sama (Tamin. O. Z., 1994).

\subsection{Model Transportasi}

Pemodelan transportasi merupakan proses penyebaran matrik asal tujuan pada suatu jaringan jalan sehingga menghasilkan arus lalu lintas pada tahun rencana, sebagaimana Matrik Asal Tujuan (MAT) merupakan masukan utama yang paling sering digunakan dalam berbagai macam perencanaan transportasi (Fakhri N, 2016).

1. Daerah Kajian

Daerah yang akan dikaji mencakup wilayah suatu kota, akan tetapi harus dapat mencakup ruang atau daerah yang cukup untuk pengembangan kota dimasa mendatang pada tahun rencana (Tamin. O. Z., 2000).

2. Zona Kajian

Zona merupakan suatu satuan ruang dalam tahapan perencanaan transportasi yang mewakili suatu wilayah tertentu yang memiliki karakteristik tertentu pula. Salah satu hal yang mendasar pada proses pembagian zona adalah identifikasi sistem kegiatan (guna lahan) yang signifikan terjadi di wilayah tersebut, dan identifikasi tingkat keseragaman tata guna lahan yang diwakili oleh masing-masing zona (Tamin. O. Z., 2000).

\subsection{Model Bangkitan dan Tarikan Pergerakan}

Analisis regresi-linear adalah metode statistik yang dignakan untuk mempelajari hubungan antarsifat permasalahan yang sedang diselidiki. Model analisis regresi-linear memodelkan hubungan antara dua peubah atau lebih (Tamin. O. Z., 2000).

Secara umum dapat dinyatakan dalam Persamaan 1.

$$
Y=A+B X
$$

dengan:

$Y=$ peubah tidak bebas,

$X=$ peubah bebas,

$A=$ intersep atau konstanta regresi,

$B=$ koefisien regresi.

Nilai parameter $A$ dan $B$ bisa didapatkan dari Persamaan 2 dan Persamaan 3.

$$
\begin{gathered}
B=\frac{N \sum(X i Y i)-\sum(X i) \sum(Y i)}{N \sum\left(X i^{2}\right)-\left(\sum(X i)\right)^{2}} \\
A=\bar{Y}-B \bar{X}
\end{gathered}
$$

$\bar{Y}$ dan $\bar{X}$ adalah nilai rata-rata dari $Y_{i}$ dan $X_{i}$. 


\subsection{Model Sebaran Peregerakan}

Metode Furness yang dikembangkan oleh Furness 1965 sebaran pergerakan pada masa mendatang didapatkan dengan mengalikan sebaran pergerakan pada saat sekarang dengan tingkat pertumbuhan zona asal atau zona tujuan yang dilakukan secara bergantian. Pada metode ini pergerakan awal (masa sekarang) pertama kali dikalikan dengan tingkat pertumbuhan zona asal. Hasilnya kemudian dikalikan dengan tingkat pertumbuhan zona tujuan dan zona asal secara bergantian sampai total sel MAT untuk setiap arah (baris atau kolom) kira-kira sama dengan total sel MAT yang diinginkan (Tamin. O. Z., 2000). Secara umum, metode Furness dapat dinyatakan pada Persamaan 4.

$$
T_{i d}=t_{i d} * E_{i}
$$

dengan:

$T_{i d}=$ jumlah pergerakan dari zona $i$ ke zona d pada masa yang akan datang,

$t_{i d}=$ jumlah pergerakan dari zona $i$ ke zona d pada saat sekarang,

$E_{i}=$ faktor pertumbuhan .

\subsection{Ruas Jalan}

Beberapa ciri ruas jalan yang perlu diketahui, seperti panjang, kecepatan, jumlah lajur, jenis gangguan samping, dan kapasitas di ruas jalan tersebut.

1. Kecepatan Arus Bebas (FV)

Menurut MKJI 1997, kecepatan arus bebas ( $F V$ ) didefinisikan sebagai kecepatan paada tingkat arus nol, yaitu kecepatan yang akan dipilih pengemudi jika mengendarai kendaraan bermotor tanpa dipengaruhi oleh kendaraan bermotor lain di jalan. Persamaan untuk penentuan kecepatan arus bebas mempunyai bentuk umum pada Persamaan 5.

$$
F V=\left(F V_{0}+F V_{W}\right) * F V_{S F} * F F V_{R C}
$$

dengan:

$F V \quad=$ kecepatan arus bebas pada kondisi lapangan $[\mathrm{km} / \mathrm{jam}]$,

$F V_{0} \quad=$ kecepatan arus bebas dasar pada jalan yang diamati $[\mathrm{km} / \mathrm{jam}]$,

$F V_{W} \quad=$ penyesuaian akibat lebar jalur lalu lintas $[\mathrm{km} / \mathrm{jam}]$,

$F V_{S F} \quad=$ paktor penyesuaian untuk hambatan samping dan lebar bahu,

$F F V_{R C}=$ faktor penyesuaian akibat kelas fungsional jalan dan tata guna lahan.

2. Kapasitas Jalan $(\boldsymbol{C})$

Perhitungan kapasitas jalan didasarkan pada Manual Kapasitas Jalan Indonesia (MKJI) tahun 1997. Perhitungan kapasitas dapat dilihat pada Persamaan 6.

$$
C=C_{0} * F C_{W} * F C_{S P} * F C_{S F} * F C_{C S}
$$

dengan:

$C \quad=$ kapasitas [smp/jam],

$C_{0} \quad=$ kapasitas dasar [smp/jam],

$F C_{W} \quad=$ faktor koreksi kapasitas untuk lebar jalan,

$F C_{S P}=$ faktor koreksi kapasitas akibat pembagian arah,

$F C_{S F} \quad$ = faktor koreksi kapasitas akibat gangguan samping, 
$F C_{C S} \quad=$ faktor koreksi kapasitas akibat ukuran kota.

\subsection{Derajat Kejenuhan (DS)}

Menurut MKJI 1997, derajat kejenuhan ( $D S$ ) didefinisikan sebagai rasio terhadap kapasitas, digunakan sebagai faktor utama dalam penetuan tingkat kinerja simpang dan segmen jalan. Perhitungan derajat kejenuhan dapat dilihat pada Persamaan 7.

$$
D S=\frac{Q}{C}
$$

dengan:

$$
\begin{array}{ll}
D S & =\text { derajat kejenuhan, } \\
Q & =\text { arus lalu lintas [smp/jam] } \\
C & =\text { kapasitas [smp/jam]. }
\end{array}
$$

\section{METODE PENELITIAN}

\subsection{Prosedur Penelitian}

Penelitian ini dilakukan dengan merumuskan masalah yaitu melakukan pemodelan transportasi empat tahap dan pembebanan lalu lintas dengan metode Keseimbangan Wardrop menggunakan aplikasi PTV Visum. Setelah dilakukan pembebanan lalu lintas, didapat arus lalu lintas pada ruas jalan yang ditinjau. Selanjutnya dilakukan validasi arus lalu lintas model dengan arus lalu lintas sekunder lapangan. Pada tahap validasi tersebut dapat disimpulkan apakah data model memiliki nilai arus yang mendekati atau tidak dengan data sekunder lapangan.

\subsection{Data Penelitian}

Data sekunder yang digunakan pada penelitian ini berasal dari studi literatur. Data ini terdiri dari:

1. Peta trase jaringan jalan Trans Bangka.

2. Arus lalu lintas kendaraan pada suatu ruas jalan.

3. Prediksi populasi penduduk tiap zona.

4. Prediksi Produk Domestik Regional Bruto (PDRB) tiap zona.

5. Prediksi jumlah bangkitan dan tarikan perjalanan penumpang dan barang tiap zona pada jalan Trans Bangka.

6. Matrik asal tujuan rencana.

\section{ANALISIS DAN PEMBAHASAN}

\subsection{Perhitungan Manual}

Analisis dengan menggunakan PTV Visum 16 dilakukan secara bertahap dengan data awal pada tahun 2011, mulai dari proyeksi penduduk dan PDRB, proyeksi bangkitan dan tarikan perjalanan penumpang dan barang, matrik asal tujuan rencana, mengolah data jaringan jalan hingga mendapatkan hasil berupa volume lalu lintas pada setiap ruas jalan yang ditinjau. Analisis perhitungan dilakukan sebagai berikut:

1. Proyeksi jumlah populasi penduduk untuk tiap zona pada tahun 2020 dapat dilihat pada Tabel 1. Hasil didapat dari perhitungan dengan cara analisis regresi linier dengan variabel $(X)$ adalah tahun 2011-2016 dan variabel $(Y)$ adalah jumlah populasi penduduknya. 
Tabel 1. Proyeksi Jumlah Populasi Penduduk untuk Tiap Zona Tahun 2020

\begin{tabular}{ccccccccc}
\hline \multicolumn{10}{c}{ Populasi Penduduk [orang/tahun] } \\
\hline Tahun & Bangka & $\begin{array}{c}\text { Bangka } \\
\text { Selatan }\end{array}$ & $\begin{array}{c}\text { Bangka } \\
\text { Tengah }\end{array}$ & $\begin{array}{c}\text { Bangka } \\
\text { Barat }\end{array}$ & $\begin{array}{c}\text { Kota Pangkal } \\
\text { Pinang }\end{array}$ & $\begin{array}{c}\text { Provinsi } \\
\text { Sumsel }\end{array}$ & $\begin{array}{c}\text { Provinsi } \\
\text { Lampung }\end{array}$ \\
\hline 2020 & 343.315 & 213.594 & 199.791 & 217.032 & 216.783 & 8.625 .181 & 8.585 .597 \\
\hline
\end{tabular}

2. Proyeksi produk domestik regional bruto (PDRB) untuk tiap zona pada tahun 2020 dapat dilihat pada Tabel 2. Hasil didapat dari perhitungan dengan cara analisis regresi linier dengan variabel $(X)$ adalah tahun 2011-2016 dan variabel $(Y)$ adalah PDRB.

Tabel 2. Proyeksi PDRB untuk Tiap Zona Tahun 2020

\begin{tabular}{ccccccccc}
\hline \multicolumn{8}{c}{ Produk Domestik Regional Bruto [Juta Rupiah] } \\
\hline Tahun & Bangka & $\begin{array}{c}\text { Bangka } \\
\text { Selatan }\end{array}$ & $\begin{array}{c}\text { Bangka } \\
\text { Tengah }\end{array}$ & $\begin{array}{c}\text { Bangka } \\
\text { Barat }\end{array}$ & $\begin{array}{c}\text { Kota Pangkal } \\
\text { Pinang }\end{array}$ & $\begin{array}{c}\text { Provinsi } \\
\text { Sumsel }\end{array}$ & $\begin{array}{c}\text { Provinsi } \\
\text { Lampung }\end{array}$ \\
\hline 2020 & 15.329 .156 & 9.750 .828 & 9.892 .229 & 16.283 .106 & 14.765 .526 & 473.301 .670 & 350.248 .703 \\
\hline
\end{tabular}

3. Proyeksi bangkitan perjalanan penumpang untuk tiap zona pada tahun 2020 dapat dilihat pada Tabel 3. Hasil didapat dari grafik dengan perhitungan cara analisis regresi linier dengan variabel $(X)$ adalah populasi penduduk dan variabel $(Y)$ adalah bangkitan perjalanan penumpang.

Tabel 3. Proyeksi Bangkitan Perjalanan Penumpang untuk Tiap Zona

\begin{tabular}{cccccccc}
\hline & \multicolumn{6}{c}{ Bangkitan Penumpang [orang/tahun] } \\
\cline { 2 - 8 } Tahun & Bangka & $\begin{array}{c}\text { Bangka } \\
\text { Selatan }\end{array}$ & $\begin{array}{c}\text { Bangka } \\
\text { Tengah }\end{array}$ & $\begin{array}{c}\text { Bangka } \\
\text { Barat }\end{array}$ & $\begin{array}{c}\text { Kota Pangkal } \\
\text { Pinang }\end{array}$ & $\begin{array}{c}\text { Provinsi } \\
\text { Sumsel }\end{array}$ & $\begin{array}{c}\text { Provinsi } \\
\text { Lampung }\end{array}$ \\
\hline 2020 & 638.067 & 420.564 & 397.421 & 426.329 & 425.911 & 14.524 .272 & 14.457 .901 \\
\hline
\end{tabular}

4. Proyeksi tarikan perjalanan penumpang untuk tiap zona pada tahun 2020 dapat dilihat pada Tabel 4. Hasil didapat dari grafik dengan perhitungan cara analisis regresi linier dengan variabel $(X)$ adalah populasi penduduk dan variabel $(Y)$ adalah tarikan perjalanan penumpang.

Tabel 4. Proyeksi Tarikan Perjalanan Penumpang untuk Tiap Zona

\begin{tabular}{ccccccccc}
\hline \multirow{2}{*}{ Tahun } & \multicolumn{7}{c}{ Tarikan Penumpang [orang/tahun] } \\
\cline { 2 - 8 } & Bangka & $\begin{array}{c}\text { Bangka } \\
\text { Selatan }\end{array}$ & $\begin{array}{c}\text { Bangka } \\
\text { Tengah }\end{array}$ & $\begin{array}{c}\text { Bangka } \\
\text { Barat }\end{array}$ & $\begin{array}{c}\text { Kota Pangkal } \\
\text { Pinang }\end{array}$ & $\begin{array}{c}\text { Provinsi } \\
\text { Sumsel }\end{array}$ & $\begin{array}{c}\text { Provinsi } \\
\text { Lampung }\end{array}$ \\
\hline 2020 & 642.020 & 424.764 & 401.646 & 430.520 & 430.105 & 14.512 .489 & 14.446 .193 \\
\hline
\end{tabular}

5. Proyeksi bangkitan perjalanan barang untuk tiap zona pada tahun 2020 dapat dilihat pada Tabel 5. Hasil didapat dari grafik dengan perhitungan cara analisis regresi linier dengan variabel $(X)$ adalah PDRB dan variabel $(Y)$ adalah bangkitan perjalanan barang.

Tabel 5. Proyeksi Bangkitan Perjalanan Barang untuk Tiap Zona

\begin{tabular}{cccccccc}
\hline \multirow{2}{*}{ Tahun } & \multicolumn{7}{c}{ Bangkitan Barang [ton/tahun] } \\
\cline { 2 - 8 } & Bangka & $\begin{array}{c}\text { Bangka } \\
\text { Selatan }\end{array}$ & $\begin{array}{c}\text { Bangka } \\
\text { Tengah }\end{array}$ & $\begin{array}{c}\text { Bangka } \\
\text { Barat }\end{array}$ & $\begin{array}{c}\text { Kota Pangkal } \\
\text { Pinang }\end{array}$ & $\begin{array}{c}\text { Provinsi } \\
\text { Sumsel }\end{array}$ & $\begin{array}{c}\text { Provinsi } \\
\text { Lampung }\end{array}$ \\
\hline 2020 & 2.174 .730 & 1.511 .466 & 1.528 .279 & 2.288 .154 & 2.107 .714 & 56.627 .662 & 41.996 .664 \\
\hline
\end{tabular}


6. Proyeksi tarikan perjalanan barang untuk tiap zona pada tahun 2020 dapat dilihat pada Tabel 6. Hasil didapat dari grafik dengan perhitungan cara analisis regresi linier dengan variabel $(X)$ adalah PDRB dan variabel $(Y)$ adalah tarikan perjalanan barang.

Tabel 6. Proyeksi Tarikan Perjalanan Barang untuk Tiap Zona

\begin{tabular}{cccccccc}
\hline \multirow{2}{*}{ Tahun } & \multicolumn{7}{c}{ Tarikan Barang [ton/tahun] } \\
\cline { 2 - 8 } & Bangka & $\begin{array}{c}\text { Bangka } \\
\text { Selatan }\end{array}$ & $\begin{array}{c}\text { Bangka } \\
\text { Tengah }\end{array}$ & $\begin{array}{c}\text { Bangka } \\
\text { Barat }\end{array}$ & $\begin{array}{c}\text { Kota Pangkal } \\
\text { Pinang }\end{array}$ & $\begin{array}{c}\text { Provinsi } \\
\text { Sumsel }\end{array}$ & $\begin{array}{c}\text { Provinsi } \\
\text { Lampung }\end{array}$ \\
\hline 2020 & 1.408 .016 & 768.306 & 426.023 & 1.077 .819 & 856.652 & 61.122 .795 & 45.150 .520 \\
\hline
\end{tabular}

7. Konversi bangkitan dan tarikan perjalanan penumpang tahun 2020 dari satuan orang per tahun diubah menjadi satuan smp/jam. Untuk presentase dalam pembagi jenis kendaraan yaitu bus sebesar $20 \%$, mobil sebesar $50 \%$ dan motor sebesar $30 \%$. Asumsi yang digunakan pada perhitungan ini yaitu untuk 1 bus 25 orang penumpang, 1 mobil 3 orang penumpang, dan 1 motor 2 orang penumpang. Setelah itu untuk menjadi smp/jam dikalikan faktor ekivalensi penumpang. Hasil konversi bangkitan perjalanan penumpang tahun 2020 dapat dilihat pada Tabel 7 dan tarikan pada Tabel 8.

Tabel 7. Konversi Bangkitan Perjalanan Kendaraan Penumpang untuk Tiap Zona Tahun 2020

\begin{tabular}{|c|c|c|c|c|c|c|c|c|}
\hline \multirow{2}{*}{\multicolumn{2}{|c|}{ Jenis Kendaraan }} & \multicolumn{7}{|c|}{ Bangkitan } \\
\hline & & \multirow{2}{*}{$\begin{array}{l}\text { Bangka } \\
638.067 \\
\end{array}$} & \multirow{2}{*}{$\begin{array}{l}\text { Bangka } \\
\text { Selatan } \\
420.564 \\
\end{array}$} & \multirow{2}{*}{$\begin{array}{c}\text { Bangka } \\
\text { Barat } \\
426.329\end{array}$} & \multirow{2}{*}{$\begin{array}{l}\text { Bangka } \\
\text { Tengah } \\
397.421\end{array}$} & \multirow{2}{*}{$\begin{array}{c}\begin{array}{c}\text { Pangkal } \\
\text { Pinang }\end{array} \\
425.911 \\
\end{array}$} & \multirow{2}{*}{$\begin{array}{c}\text { Sumatera } \\
\text { Selatan }\end{array}$} & \multirow{2}{*}{$\begin{array}{l}\text { Lampung } \\
14.457 .901\end{array}$} \\
\hline & [orang/tahun] & & & & & & & \\
\hline Mobil, & [orang/hari] & 1.748 & 1.152 & 1.168 & 1.089 & 1.167 & 3.9793 & 3.9611 \\
\hline Motor & [orang/jam] & 175 & 115 & 117 & 109 & 117 & 3.979 & 3.961 \\
\hline \multirow{3}{*}{ Bus } & $20 \%$ & 35 & 23 & 23 & 22 & 23 & 796 & 792 \\
\hline & [kend/jam] & 1 & 1 & 1 & 1 & 1 & 32 & 32 \\
\hline & [smp/jam] & 2 & 1 & 1 & 1 & 1 & 41 & 41 \\
\hline \multirow{3}{*}{ Mobil } & $50 \%$ & 87 & 58 & 58 & 54 & 58 & 1.990 & 1.981 \\
\hline & [kend/jam] & 29 & 19 & 19 & 18 & 19 & 663 & 660 \\
\hline & [smp/jam] & 29 & 19 & 19 & 18 & 19 & 663 & 660 \\
\hline \multirow{3}{*}{ Motor } & $30 \%$ & 52 & 35 & 35 & 33 & 35 & 1.194 & 1.188 \\
\hline & [kend/jam] & 26 & 17 & 18 & 16 & 18 & 597 & 594 \\
\hline & [smp/jam] & 10 & 7 & 7 & 7 & 7 & 239 & 238 \\
\hline
\end{tabular}

Tabel 8. Konversi Tarikan Perjalanan Kendaraan Penumpang untuk Tiap Zona Tahun 2020

\begin{tabular}{|c|c|c|c|c|c|c|c|c|}
\hline \multirow{2}{*}{\multicolumn{2}{|c|}{ Jenis Kendaraan }} & \multicolumn{7}{|c|}{ Tarikan } \\
\hline & & \multirow{2}{*}{$\begin{array}{l}\text { Bangka } \\
642.020\end{array}$} & \multirow{2}{*}{$\begin{array}{l}\begin{array}{l}\text { Bangka } \\
\text { Selatan }\end{array} \\
424.764\end{array}$} & \multirow{2}{*}{$\begin{array}{c}\begin{array}{c}\text { Bangka } \\
\text { Barat }\end{array} \\
430.520 \\
\end{array}$} & \multirow{2}{*}{$\begin{array}{l}\text { Bangka } \\
\text { Tengah } \\
401.646\end{array}$} & \multirow{2}{*}{$\begin{array}{c}\begin{array}{c}\text { Pangkal } \\
\text { Pinang }\end{array} \\
430.105 \\
\end{array}$} & \multirow{2}{*}{$\begin{array}{c}\begin{array}{c}\text { Sumatera } \\
\text { Selatan }\end{array} \\
14.512 .489\end{array}$} & \multirow{2}{*}{$\begin{array}{l}\text { Lampung } \\
14.446 .193\end{array}$} \\
\hline \multirow{3}{*}{$\begin{array}{l}\text { Bus, } \\
\text { Mobil, } \\
\text { Motor }\end{array}$} & [orang/tahun] & & & & & & & \\
\hline & [orang/hari] & 1.759 & 1.164 & 1.180 & 1.100 & 1.178 & 39.760 & 39.579 \\
\hline & [orang/jam] & 176 & 116 & 118 & 110 & 118 & 3.976 & 3.958 \\
\hline \multirow{3}{*}{ Bus } & $20 \%$ & 35 & 23 & 24 & 22 & 24 & 795 & 792 \\
\hline & [kend/jam] & 1 & 5 & 5 & 4 & 5 & 159 & 158 \\
\hline & [smp/jam] & 2 & 6 & 6 & 6 & 6 & 207 & 206 \\
\hline
\end{tabular}


Tabel 8. Konversi Tarikan Perjalanan Kendaraan Penumpang untuk Tiap Zona Tahun 2020 lanjutan

\begin{tabular}{|c|c|c|c|c|c|c|c|c|}
\hline \multirow{2}{*}{\multicolumn{2}{|c|}{ Jenis Kendaraan }} & \multicolumn{7}{|c|}{ Tarikan } \\
\hline & & \multirow{2}{*}{$\begin{array}{c}\text { Bangka } \\
88\end{array}$} & \multirow{2}{*}{$\begin{array}{c}\text { Bangka } \\
\text { Selatan } \\
58\end{array}$} & \multirow{2}{*}{$\begin{array}{c}\text { Bangka } \\
\text { Barat }\end{array}$} & \multirow{2}{*}{$\begin{array}{c}\text { Bangka } \\
\text { Tengah } \\
55 \\
\end{array}$} & \multirow{2}{*}{$\begin{array}{c}\text { Pangkal } \\
\text { Pinang } \\
59\end{array}$} & \multirow{2}{*}{$\begin{array}{c}\begin{array}{c}\text { Sumatera } \\
\text { Selatan }\end{array} \\
1.988\end{array}$} & \multirow{2}{*}{$\begin{array}{c}\text { Lampung } \\
1.979\end{array}$} \\
\hline \multirow{3}{*}{ Mobil } & $50 \%$ & & & & & & & \\
\hline & [kend/jam] & 59 & 39 & 39 & 37 & 39 & 1.325 & 1.319 \\
\hline & [smp/jam] & 59 & 39 & 39 & 37 & 39 & 1.325 & 1.319 \\
\hline \multirow{3}{*}{ Motor } & $30 \%$ & 53 & 35 & 35 & 33 & 35 & 1.193 & 1.187 \\
\hline & [kend/jam] & 88 & 58 & 59 & 55 & 59 & 1.988 & 1.979 \\
\hline & [smp/jam] & 35 & 23 & 24 & 22 & 24 & 795 & 792 \\
\hline
\end{tabular}

8. Konversi bangkitan dan tarikan perjalanan barang tahun 2020 dari satuan ton per tahun diubah menjadi satuan smp/jam. Asumsi yang digunakan pada perhitungan ini yaitu 1 truck 3 ton barang. Hasil konversi bangkitan perjalanan penumpang tahun 2020 dapat dilihat pada Tabel 9 dan tarikan pada Tabel 10.

Tabel 9. Konversi Bangkitan Perjalanan Kendaraan Barang untuk Tiap Zona Tahun 2020

\begin{tabular}{|c|c|c|c|c|c|c|c|c|}
\hline \multirow{2}{*}{\multicolumn{2}{|c|}{ Jenis Kendaraan }} & \multicolumn{7}{|c|}{ Bangkitan } \\
\hline & & Bangka & $\begin{array}{l}\text { Bangka } \\
\text { Selatan }\end{array}$ & $\begin{array}{c}\text { Bangka } \\
\text { Barat }\end{array}$ & $\begin{array}{l}\text { Bangka } \\
\text { Tengah }\end{array}$ & $\begin{array}{l}\text { Pangkal } \\
\text { Pinang }\end{array}$ & $\begin{array}{c}\text { Sumatera } \\
\text { Selatan }\end{array}$ & Lampung \\
\hline \multirow{5}{*}{ Truk } & [ton/tahun] & 2.174 .730 & 1.511 .466 & 2.288 .154 & 1.528 .279 & 2.107 .714 & 56.627 .662 & 41.996 .664 \\
\hline & [ton/hari] & 5.958 & 4.141 & 6.269 & 4.187 & 5.775 & 155.144 & 115.059 \\
\hline & [ton/jam] & 596 & 414 & 627 & 419 & 577 & 15.514 & 11.506 \\
\hline & [kend/jam] & 199 & 138 & 209 & 140 & 192 & 5.171 & 3.835 \\
\hline & [smp/jam] & 258 & 179 & 272 & 181 & 250 & 6.723 & 4.986 \\
\hline
\end{tabular}

Tabel 10. Konversi Tarikan Perjalanan Kendraan Barang untuk Tiap Zona Tahun 2020

\begin{tabular}{|c|c|c|c|c|c|c|c|c|}
\hline \multirow{2}{*}{\multicolumn{2}{|c|}{ Jenis Kendaraan }} & \multicolumn{7}{|c|}{ Tarikan } \\
\hline & & Bangka & $\begin{array}{l}\text { Bangka } \\
\text { Selatan }\end{array}$ & $\begin{array}{c}\text { Bangka } \\
\text { Barat }\end{array}$ & $\begin{array}{l}\text { Bangka } \\
\text { Tengah }\end{array}$ & $\begin{array}{c}\text { Pangkal } \\
\text { Pinang }\end{array}$ & $\begin{array}{c}\text { Sumatera } \\
\text { Selatan }\end{array}$ & Lampung \\
\hline \multirow{5}{*}{ Truk } & [ton/tahun] & 1.677 .962 & 953.895 & 1.801 .785 & 972.249 & 1.604 .803 & 61.122 .795 & 45.150 .520 \\
\hline & [ton/hari] & 4.597 & 2.613 & 4.936 & 2.664 & 4.397 & 167.460 & 123.700 \\
\hline & [ton/jam] & 460 & 261 & 494 & 266 & 440 & 167.46 & 12.370 \\
\hline & [kend/jam] & 153 & 87 & 165 & 89 & 147 & 5.582 & 4.123 \\
\hline & [smp/jam] & 199 & 113 & 214 & 115 & 191 & 7.257 & 5.360 \\
\hline
\end{tabular}

9. Metode yang digunakan dalam prediksi Matrik Asal Tujuan (MAT) rencana pada penelitian ini menggunakan metode Furness. Prediksi MAT rencana dilakukan dari tahun 2016 data sekunder yang telah divalidasi hasil arusnya dengan model ke tahun 2020 dengan satuan yang telah dikalikan koefisien satuan mobil penumpang (smp/jam). Prediksi MAT rencana tahun 2016 dapat dilihat pada Tabel 11. Prediksi MAT rencana penumpang tahun 2020 dapat dilihat pada Tabel $\mathbf{1 2}$ dan prediksi MAT rencana barang dapat dilihat pada Tabel 13. 
Tabel 11. Prediksi Matrik Asal Tujuan Rencana Tahun 2016

\begin{tabular}{|c|c|c|c|c|c|c|c|c|}
\hline \multirow{3}{*}{ ASAL } & \multicolumn{8}{|c|}{ TUJUAN } \\
\hline & Bangka & $\begin{array}{l}\text { Bangka } \\
\text { Selatan }\end{array}$ & $\begin{array}{l}\text { Bangka } \\
\text { Tengah }\end{array}$ & $\begin{array}{c}\text { Bangka } \\
\text { Barat }\end{array}$ & $\begin{array}{c}\text { Kota } \\
\text { Pangkal } \\
\text { Pinang }\end{array}$ & $\begin{array}{l}\text { Provinsi } \\
\text { Sumsel }\end{array}$ & $\begin{array}{l}\text { Provinsi } \\
\text { Lampung }\end{array}$ & Total \\
\hline & \multicolumn{8}{|c|}{ [smp/jam] } \\
\hline Bangka & - & 10 & 17 & 19 & 44 & 132 & 115 & 337 \\
\hline Bangka Selatan & 9 & - & 13 & 6 & 9 & 95 & 107 & 239 \\
\hline Bangka Tengah & 19 & 13 & - & 7 & 18 & 95 & 91 & 243 \\
\hline Bangka Barat & 15 & 5 & 8 & - & 11 & 174 & 106 & 319 \\
\hline Kota Pangkal Pinang & 43 & 7 & 18 & 14 & - & 117 & 100 & 299 \\
\hline Provinsi Sumsel & 101 & 68 & 66 & 137 & 87 & - & 5.832 & 6.291 \\
\hline Provinsi Lampung & 119 & 104 & 89 & 106 & 99 & 7.414 & - & 7.931 \\
\hline Total & 306 & 207 & 211 & 289 & 268 & 8.027 & 6.351 & 15.659 \\
\hline
\end{tabular}

Tabel 12. Prediksi Matrik Asal Tujuan Rencana Penumpang Tahun 2020

\begin{tabular}{|c|c|c|c|c|c|c|c|c|}
\hline \multirow{3}{*}{ ASAL } & \multicolumn{8}{|c|}{ TUJUAN } \\
\hline & Bangka & $\begin{array}{l}\text { Bangka } \\
\text { Selatan }\end{array}$ & $\begin{array}{l}\text { Bangka } \\
\text { Tengah }\end{array}$ & $\begin{array}{c}\text { Bangka } \\
\text { Barat }\end{array}$ & $\begin{array}{l}\text { Pangkal } \\
\text { Pinang }\end{array}$ & $\begin{array}{l}\text { Provinsi } \\
\text { Sumsel }\end{array}$ & $\begin{array}{l}\text { Provinsi } \\
\text { Lampung }\end{array}$ & Total \\
\hline & \multicolumn{8}{|c|}{ [smp/jam] } \\
\hline Bangka & - & 4 & 7 & 8 & 13 & 37 & 32 & 102 \\
\hline Bangka Selatan & 3 & - & 5 & 2 & 3 & 25 & 28 & 67 \\
\hline Bangka Tengah & 6 & 4 & - & 2 & 6 & 23 & 23 & 64 \\
\hline Bangka Barat & 5 & 2 & 3 & - & 3 & 35 & 21 & 69 \\
\hline Kota Pangkal Pinang & 10 & 2 & 6 & 4 & - & 25 & 22 & 69 \\
\hline Provinsi Sumsel & 37 & 25 & 24 & 51 & 32 & - & 2.159 & 2.329 \\
\hline Provinsi Lampung & 35 & 30 & 26 & 31 & 29 & 2.167 & - & 2318 \\
\hline Total & 96 & 68 & 71 & 99 & 87 & 2.312 & 2.285 & 5.017 \\
\hline
\end{tabular}

Tabel 13. Prediksi Matrik Asal Tujuan Rencana Barang Tahun 2020

\begin{tabular}{cccccccccc}
\hline & \multicolumn{10}{c}{ TUJUAN } \\
\cline { 2 - 11 } ASAL & Bangka & $\begin{array}{c}\text { Bangka } \\
\text { Selatan }\end{array}$ & $\begin{array}{c}\text { Bangka } \\
\text { Tengah }\end{array}$ & $\begin{array}{c}\text { Bangka } \\
\text { Barat }\end{array}$ & \begin{tabular}{c} 
Pangkal \\
Pinang \\
\cline { 2 - 11 } [smp/jam]
\end{tabular} & $\begin{array}{c}\text { Provinsi } \\
\text { Sumsel }\end{array}$ & $\begin{array}{c}\text { Provinsi } \\
\text { Lampung }\end{array}$ & Total \\
\hline Bangka & - & 8 & 13 & 15 & 34 & 101 & 88 & 258 \\
\hline Bangka Selatan & 7 & - & 10 & 4 & 7 & 71 & 80 & 179 \\
\hline Bangka Tengah & 14 & 10 & - & 5 & 13 & 71 & 68 & 181 \\
\hline Bangka Barat & 13 & 4 & 7 & - & 9 & 148 & 90 & 272 \\
\hline Kota Pangkal Pinang & 36 & 6 & 15 & 12 & - & 98 & 84 & 250 \\
\hline Provinsi Sumsel & 108 & 73 & 71 & 146 & 93 & - & 6.232 & 6.723 \\
\hline Provinsi Lampung & 75 & 65 & 56 & 67 & 62 & 4.661 & - & 4.986 \\
\hline Total & 252 & 166 & 171 & 249 & 218 & 5.150 & 6.642 & 12.849 \\
\hline
\end{tabular}




\subsection{Pembahasan}

Data yang di hasilkan berupa perbandingan antara arus lalu lintas di lapangan dengan arus yang didapat dari PTV Visum 16 dengan masukkan data kapasitas jalan sebesar 2736 smp/jam. Hasil data validasi dapat dilihat pada Tabel 14 dan validasi berupa grafik dapat dilihat pada Gambar 1. Selanjutnya prediksi arus lalu lintas pada tahun 2020 dapat dilihat pada Tabel 15.

Tabel 14. Validasi Arus Lalu Lintas

\begin{tabular}{|c|c|c|c|}
\hline \multirow{3}{*}{ Nama Ruas Jalan } & \multirow{3}{*}{ Dari Arah } & Arus Lapangan & Arus Model \\
\hline & & $X$ & $Y$ \\
\hline & & [smp/jam] & [smp/jam] \\
\hline \multirow{2}{*}{ Pangkalpinang - Jebus } & Jebus & 181 & 305 \\
\hline & Pangkalpinang & 161 & 253 \\
\hline \multirow{2}{*}{ Pangkalpinang - Muntok } & Muntok & 384 & 385 \\
\hline & Pangkalpinang & 420 & 512 \\
\hline \multirow{2}{*}{ Koba - Toboali } & Koba & 532 & 540 \\
\hline & Toboali & 383 & 490 \\
\hline \multirow{2}{*}{ Pangkalpinang - Sungai Selan } & Sungai Selan & 210 & 247 \\
\hline & Pangkalpinang & 242 & 349 \\
\hline \multirow{2}{*}{ Kelapa - Puding } & Kelapa & 230 & 268 \\
\hline & Puding & 192 & 203 \\
\hline
\end{tabular}

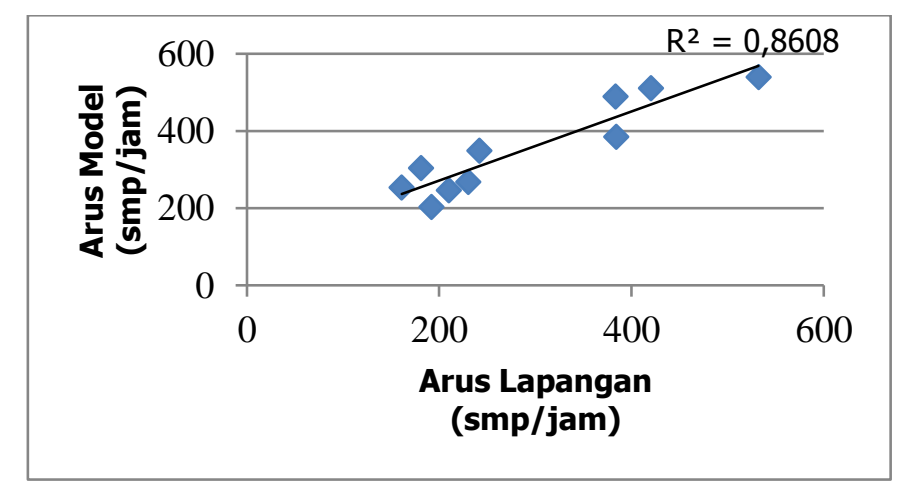

Gambar 1. Grafik validasi arus lapangan-arus model

Tabel 15. Prediksi Arus Lalu Lintas Jalan Trans Bangka Tahun 2020

\begin{tabular}{|c|c|c|c|c|c|c|}
\hline \multirow{3}{*}{$\begin{array}{c}\text { Nama Ruas Jalan } \\
\text { Baru Trans } \\
\text { Bangka }\end{array}$} & \multirow{3}{*}{ Dari Arah } & \multicolumn{2}{|c|}{ Kendaraan Penumpang } & \multicolumn{2}{|c|}{ Kendaraan Barang } & \multirow{3}{*}{$\begin{array}{c}\begin{array}{c}\text { Derajat } \\
\text { Kejenuhan }\end{array} \\
D S \\
{[\%]}\end{array}$} \\
\hline & & Arus & Kecepatan & Arus & Kecepatan & \\
\hline & & [smp/jam] & [km/jam] & [smp/jam] & {$[\mathrm{km} / \mathrm{jam}]$} & \\
\hline \multirow{2}{*}{$\begin{array}{l}\text { Permis - Bts. Kab. } \\
\text { Bangka tengah dan } \\
\text { Bangka Selatan }\end{array}$} & Permis & 225 & 57 & 219 & 56 & 11 \\
\hline & Bts Kab & 240 & 57 & 211 & 56 & 11 \\
\hline \multirow{2}{*}{ Tj. Gusung - Permis } & Tj Gusung & 114 & 49 & 166 & 50 & 10 \\
\hline & Permis & 111 & 49 & 163 & 50 & 10 \\
\hline \multirow{2}{*}{$\begin{array}{l}\text { Jl. Damai - Jl. } \\
\text { Merdeka }\end{array}$} & JI Damai & 111 & 49 & 103 & 49 & 6 \\
\hline & Jl Merdeka & 114 & 49 & 109 & 49 & 7 \\
\hline
\end{tabular}


Tabel 15. Prediksi Arus Lalu Lintas Jalan Trans Bangka Tahun 2020 lanjutan

\begin{tabular}{|c|c|c|c|c|c|c|}
\hline \multirow{3}{*}{$\begin{array}{c}\text { Nama Ruas Jalan } \\
\text { Baru Trans } \\
\text { Bangka }\end{array}$} & \multirow{3}{*}{ Dari Arah } & \multicolumn{2}{|c|}{ Kendaraan Penumpang } & \multicolumn{2}{|c|}{ Kendaraan Barang } & \multirow{2}{*}{$\begin{array}{c}\begin{array}{c}\text { Derajat } \\
\text { Kejenuhan }\end{array} \\
D S\end{array}$} \\
\hline & & Arus & Kecepatan & Arus & Kecepatan & \\
\hline & & [smp/jam] & [km/jam] & [smp/jam] & [km/jam $]$ & [\%] \\
\hline \multirow{2}{*}{$\begin{array}{c}\text { Bts. Kab. Bangka } \\
\text { Tengah \& Selatan - } \\
\text { Komplek } \\
\text { Perkantoran Kab. } \\
\text { Bangka Selatan }\end{array}$} & $\begin{array}{c}\text { Bts Kab Bangka } \\
\text { Tengah dan } \\
\text { Bangka Selatan }\end{array}$ & 243 & 56 & 221 & 56 & 11 \\
\hline & $\begin{array}{c}\text { Komplek } \\
\text { Perkantoran } \\
\text { Kab. Bangka } \\
\text { Selatan }\end{array}$ & 228 & 56 & 204 & 54 & 11 \\
\hline \multirow{2}{*}{$\begin{array}{c}\text { Jalan Bts. Kab. } \\
\text { Bangka Tengah \& } \\
\text { Selatan (Sp. Rimba) } \\
\text { - Bts. Kab. Bangka } \\
\text { Tengah \& Bangka }\end{array}$} & Sp Rimba & 159 & 50 & 153 & 50 & 10 \\
\hline & $\begin{array}{c}\text { Bts Kab Bangka } \\
\text { Tengah dan } \\
\text { Bangka }\end{array}$ & 165 & 50 & 148 & 50 & 9 \\
\hline \multirow{2}{*}{$\begin{array}{l}\text { Tj. Berikat - Bts. } \\
\text { Kab. Bangka \& } \\
\text { Selatan Tengah }\end{array}$} & Tj Berikat & 144 & 50 & 109 & 49 & 7 \\
\hline & $\begin{array}{c}\text { Bts Kab Bangka } \\
\text { dan Selatan } \\
\text { Tengah } \\
\end{array}$ & 174 & 50 & 103 & 49 & 6 \\
\hline \multirow{2}{*}{$\begin{array}{l}\text { Desa Labuh - } \\
\text { Penagan }\end{array}$} & Desa Labuh & 147 & 50 & 155 & 50 & 9 \\
\hline & Penagan & 144 & 50 & 151 & 50 & 9 \\
\hline \multirow{2}{*}{$\begin{array}{l}\text { Kota Waringin - } \\
\text { Desa Labuh }\end{array}$} & Kota Waringin & 102 & 48 & 102 & 48 & 6 \\
\hline & Desa Labuh & 162 & 50 & 101 & 48 & 6 \\
\hline \multirow{2}{*}{$\begin{array}{l}\text { Muntok (Air Belo) - } \\
\text { Simpang Ibul }\end{array}$} & Air Belo & 156 & 50 & 235 & 56 & 12 \\
\hline & Simpang Ibul & 204 & 54 & 234 & 56 & 12 \\
\hline \multirow{2}{*}{$\begin{array}{l}\text { Kota Waringin - } \\
\text { Muntok (Air Belo) }\end{array}$} & Kota Waringin & 210 & 56 & 154 & 50 & 11 \\
\hline & Air Belo & 168 & 50 & 187 & 50 & 12 \\
\hline \multicolumn{2}{|c|}{ Rata-rata } & 170 & 52 & 165 & 51 & 9 \\
\hline
\end{tabular}

\section{KESIMPULAN}

1. Prediksi bangkitan dan tarikan perjalanan penumpang dan barang mengalami peningkatan pada tahun 2020. Hal ini dapat diartikan bahwa tahun mendatang pergerakan perjalanan penumpang dan barang yang terjadi pada jalan Trans Bangka semakin bertambah.

2. Hasil validasi antara model dengan lapangan pada tahun 2016 dapat dikatakan valid karena hasil arus model yang didapat mendekati dengan lapangan, dapat dilihat pada Gambar 2 bahwa nilai $R^{2}$ pada grafik menunjukan nilai yang mendekati 1 yaitu 0,86.

3. Pergerakan yang terjadi setelah dibangunnya jalan Trans Bangka pada tahun 2020 menunjukkan hasil arus rata-rata untuk kendaraan penumpang sebesar $170 \mathrm{smp} / \mathrm{jam}$ dnegan kecepatan $52 \mathrm{~km} / \mathrm{jam}$ dan untuk kendaraan barang sebesar $165 \mathrm{smp} / \mathrm{jam}$ dengan kecepatan $51 \mathrm{~km} / \mathrm{jam}$.

4. Derajat kejenuhan (DS) yang didapat pada jalan Trans Bangka tahun 2020 menunjukkan nilai $D S$ yang relatif kecil atau $<0,85$, hal ini dapat diartikan bahwa tidak terjadinya kemacetan atau penumpukan kendaraan pada suatu ruas jalan. 


\section{DAFTAR RUJUKAN}

Direktorat Jenderal Bina Marga. (1997). Manual Kapasitas Jalan Indonesia. Jakarta: Departemen Pekerjaan Umum.

Fakhri, N. (2016). Simulasi Pemodelan Transportasi pada Jaringan Jalan Menggunakan Saturn. Reka Racana, $2(1), 3$.

Tamin, O. Z. (1994). Aplikasi Model Perencanaan Transportasi 4 Tahap dalam Pemecahan Masalah Transportasi di Negara Sedang Berkembang. Jurnal Teknik Sipil, 3 (8), 10.

Tamin, O. Z. (2000). Perencanaan dan Pemodelan Transportasi. Bandung: Jurusan Teknik Sipil Institut Teknologi Bandung. 